\title{
Perception, passive overfeeding and energy metabolism
}

Citation for published version (APA):

Westerterp, K. R. (2006). Perception, passive overfeeding and energy metabolism. Physiology \& Behavior, 89(1), 62-65. https://doi.org/10.1016/j.physbeh.2005.12.014

Document status and date:

Published: 01/01/2006

DOI:

10.1016/j.physbeh.2005.12.014

Document Version:

Publisher's PDF, also known as Version of record

Document license:

Taverne

Please check the document version of this publication:

- A submitted manuscript is the version of the article upon submission and before peer-review. There can be important differences between the submitted version and the official published version of record.

People interested in the research are advised to contact the author for the final version of the publication, or visit the DOI to the publisher's website.

- The final author version and the galley proof are versions of the publication after peer review.

- The final published version features the final layout of the paper including the volume, issue and page numbers.

Link to publication

\footnotetext{
General rights rights.

- You may freely distribute the URL identifying the publication in the public portal. please follow below link for the End User Agreement:

www.umlib.nl/taverne-license

Take down policy

If you believe that this document breaches copyright please contact us at:

repository@maastrichtuniversity.nl

providing details and we will investigate your claim.
}

Copyright and moral rights for the publications made accessible in the public portal are retained by the authors and/or other copyright owners and it is a condition of accessing publications that users recognise and abide by the legal requirements associated with these

- Users may download and print one copy of any publication from the public portal for the purpose of private study or research.

- You may not further distribute the material or use it for any profit-making activity or commercial gain

If the publication is distributed under the terms of Article $25 \mathrm{fa}$ of the Dutch Copyright Act, indicated by the "Taverne" license above, 


\title{
Perception, passive overfeeding and energy metabolism
}

\author{
Klaas R. Westerterp * \\ Department of Human Biology, Maastricht University, PO Box 616, 6200 MD Maastricht, The Netherlands
}

Received 4 November 2005; received in revised form 22 December 2005; accepted 23 December 2005

\begin{abstract}
The palatability of a diet is an important determinant of energy intake. Due to a high palatability, a relatively high energy density, and a weak effect on satiation, the consumption of high-fat foods induces passive overfeeding. It is well known that a high-fat diet often leads to a loss of portion control of tasty foods. Here, studies are reviewed on the effect of overfeeding on substrate utilization and energy expenditure. It is often suggested that humans differ in the susceptibility to weight gain in response to overfeeding. Six years ago, non-exercise activity thermogenesis was presented as a new mechanism to explain differences in weight gain between subjects. Activation of non-exercise activity thermogenesis could dissipate excess energy to preserve leanness and only failure to activate non-exercise activity thermogenesis resulted in ready fat gain. However, there is still little evidence for this form of adaptive thermogenesis from additional studies. The conclusion is that the fat content has an effect on body fat as a function of the effect of dietary fat on energy intake.
\end{abstract}

(C) 2006 Elsevier Inc. All rights reserved.

Keywords: Fat intake; Energy intake; Energy expenditure; Respiration chamber; Doubly labeled water; Nonexercise activity thermogenesis

\section{Introduction}

Dietary fat is among the most important factors for the development of obesity [1]. The energy intake from fat has a greater effect on body weight than energy from non-fat sources. Eating high-fat foods facilitates the development of a positive energy balance by a lower satiating power than the other macronutrients [2]. The overconsumption on foods high in dietary fat is explained by the potent sensory qualities and high palatability of high-fat foods. Additionally, the energy value of fat, with $37 \mathrm{~kJ} / \mathrm{g}$, is more than twice as high as the energy value $(17 \mathrm{~kJ} / \mathrm{g})$ for carbohydrate and protein [3].

Fat, as a substrate for energy metabolism, is at the bottom of the oxidative hierarchy that determines fuel selection [4]. Changes in alcohol, carbohydrate and protein intake elicit auto regulatory adjustments in oxidation whereas a change in fat intake fails to elicit such a response. There are two types of studies showing the effect of fat intake on fat oxidation, studies where fat is supplemented in excess of energy requirements and studies on the effect of high- and low-fat diets given in energy

\footnotetext{
* Tel.: +31 43 3881628; fax: +31 433670976.

E-mail address: K.Westerterp@HB.Unimaas.NL.
}

balance. Several studies have shown that fat intake does not stimulate its own oxidation when fat is consumed in excess of energy requirements [5-7]. Schrauwen et al. [8] showed that it took a week before fat oxidation was raised sufficiently to match fat intake, when diet composition was iso-energetically switched from low-fat to high-fat.

Studies on the effect of fat intake on fat oxidation and energy balance are typically performed in the confined environment of a respiration chamber, where activity energy expenditure is about $50 \%$ of the value in daily life [9]. Physical activity might be an important factor in the development of diet-induced obesity. Levine et al. [10] showed considerable interindividual variation in the susceptibility to weight gain in response to overeating and explained two-thirds from increases in nonexercise activity thermogenesis (NEAT). Here, evidence is presented from additional studies on the effect of fat intake and overfeeding on energy balance.

\section{Methods}

Two types of studies on perception, overeating and energy metabolism will be reviewed. Firstly, studies where the percentage of fat in the diet was increased without interfering with the quantity the subjects eat, and effects are reported on energy 
balance. Secondly, studies where subjects are overfed and effects are reported on energy balance and measured energy expenditure.

There are many intervention studies where the percentage of dietary fat is changed under ad libitum food conditions. Most of the studies involve a reduction of fat intake with a fat-reduced diet. Then, the general finding is that a reduction of dietary fat causes weight loss [11]. Here, the focus will be on studies where dietary fat is increased by including high-fat foods in a diet that can be consumed ad libitum.

To study effects of overeating on individual variation in weight gain, studies were selected where subjects were overfed and effects were reported on measured energy expenditure. Here, basically two types of experimental design are available. Studies where subjects were studied under well-controlled conditions in a respiration chamber and studies where subjects were observed under normal daily living conditions and energy expenditure was measured with doubly labelled water. Respiration chamber studies typically covered interventions with a duration of some days up to a maximum of 12 days. Studies with doubly labelled water had a minimum duration of 10 to 14 days.

To study effects of dietary interventions on body mass and body composition, the size of the induced change in energy balance determines the length of the intervention for a detectable effect. For body composition, there is an uncertainty in the order of magnitude of minimally $1.5 \mathrm{~kg}$ fat mass and fatfree mass. A combination of independent measurements can reduce this measurement bias. In a three-compartment model, based on the measurement of body mass, body volume and total body water, the claimed precision is $1.0 \mathrm{~kg}$ for fat mass and $0.7 \mathrm{~kg}$ for fat-free mass [12]. The precision will never reach the level of $0.001 \mathrm{~kg}$ for body mass with integrating electronic balances. For comparative studies subjects should be measured with minimal clothing, minimal gut contents (post-absorptive) and with an empty bladder.

\section{Results}

Lissner et al. [13] performed one of the first intervention studies on the role of dietary fat in the regulation of energy intake. They measured ad libitum food consumption on three diets that were similar in appearance but differed in the amount of high-fat ingredients used. Twenty-four women each consumed a sequence of three dietary treatments in which $15-20 \%, 30-35 \%$, or $45-50 \%$ of the energy was derived from fat. Relative to their energy consumption on the medium-fat diet, the subjects spontaneously consumed an $11 \%$ deficit on the low fat diet and a $15 \%$ surfeit on the high-fat diet, resulting in significant weight changes of, respectively, -0.40 and $+0.32 \mathrm{~kg}$. Excess energy consumption on the high-fat diet was greater in the obese than the non-obese participants. We performed a study where 240 subjects were randomly assigned to either a group consuming reduced-fat products or a group consuming full-fat products for six months. Subjects visited at least once a week the laboratory to freely take food products, arranged in a shop setting. Measurements included energy intake, energy expenditure and body composition. Energy intake was measured with a 3-day food record at four times, evenly spread over the observation interval. At the start of the intervention, both groups consumed on average $35 \mathrm{en} \%$ of daily energy intake from fat. The diet intervention caused on average a change in fat intake and body fat mass in subjects of the reduced fat group of $-5 \pm$ $29 \mathrm{~g} / \mathrm{d}$ to $33 \mathrm{en} \%(P<0.05)$ and $+0.3 \pm 2.1 \mathrm{~kg}(\mathrm{~ns})$, respectively, and of $+23 \pm 31 \mathrm{~g} / \mathrm{d}$ to $41 \mathrm{en} \%(P<0.0001)$ and $+1.0 \pm 2.3 \mathrm{~kg}$ $(P<0.0001)$ in subjects of the full-fat group. The change in fat content of the diet was positively related to a change in energy intake, the latter explaining $5 \%$ of the variation in the change in body fat mass. The change in fat content of the diet had no effect on physical activity and energy expenditure. However, subjects with a higher activity level consumed more carbohydrate [14]. Subjects changing the fat content of the diet showed a consequent change in body fat mass only when energy intake changed as well [15].

Dauncey [16] measured the effect of overfeeding a diet high in fat for $24 \mathrm{~h}$ in a respiration chamber. The level of overfeeding was $74 \%$ and there was a $10 \%$ increase in $24 \mathrm{~h}$ energy expenditure (Table 1). Dallosso and James [17] overfed subjects one week with extra fat to increase energy intake by $50 \%$. Subjects had two $36 \mathrm{~h}$ sessions in a respiration chamber on a weight maintenance diet before and at the end of the overfeeding period. Energy expenditure on fat over-feeding increased by $6 \%$. Faecal energy outputs on the maintenance and over-feeding diets were $5 \%$ and $4 \%$ of the respective gross energy intakes. Zed and James [18] measured the thermogenic response of an extra $4.3 \mathrm{MJ} / \mathrm{d}$ fat given to subjects for 6 days after a preliminary weight-maintenance diet. Fat overfeeding induced an increase in energy output amounting to $10 \%$ of the supplement's energy. Horton et al. [19] fed subjects at $150 \%$ of maintenance intake over two separate 14-day periods. Over one period, excess energy was entirely provided as fat and the other period entirely as carbohydrate. A respiration chamber was used to measure energy expenditure and nutrient oxidation before and on three days during each overfeeding period. Fat overfeeding had minimal effects on fat oxidation and total energy expenditure, leading to storage of $90-95 \%$ of excess energy. Carbohydrate overfeeding resulted in $75-85 \%$ of excess

Table 1

Changes in energy expenditure during overfeeding

\begin{tabular}{lllll}
\hline Reference & $\begin{array}{l}\text { overfeeding } \\
\text { interval (d) }\end{array}$ & $\begin{array}{l}\text { overfeeding } \\
(\%)\end{array}$ & $\begin{array}{l}\text { expenditure } \\
\text { change }(\%)\end{array}$ & $\begin{array}{l}\text { expenditure change } \\
(\% \text { of overfeeding) }\end{array}$ \\
\hline$[16]$ & 1 & $74 \pm 21^{\mathrm{a}}$ & $10 \pm 6$ & $14 \pm 7$ \\
{$[17]$} & 7 & $65 \pm 14^{\mathrm{b}}$ & $6 \pm 3$ & $10 \pm 3$ \\
{$[18]$} & 6 & $50^{\mathrm{b}}$ & 5 & 10 \\
{$[19]$} & 14 & $50^{\mathrm{b}}$ & 3 & 6 \\
& & $50^{\mathrm{c}}$ & 7 & 14 \\
{$[20]$} & 12 & $33^{\mathrm{a}}$ & 6 & 18 \\
{$[19]$} & 21 & $31^{\mathrm{a}}$ & 6 & 19 \\
{$[20]$} & 42 & $49 \pm 6^{\mathrm{a}}$ & $13 \pm 15$ & $26 \pm 30$ \\
{$[10]$} & 56 & $35^{\mathrm{a}}$ & 20 & 57 \\
{$[21]$} & 14 & $45^{\mathrm{a}}$ & 4 & 9 \\
\hline
\end{tabular}

Overfeeding is expressed as \{ Intake overfeeding-Expenditure weight maintenance)/Expenditure weight maintenance $\} * 100(\%)$. The change in energy expenditure is expressed as $\{$ (Expenditure overfeeding-Expenditure weight maintenance)/Expenditure weight maintenance $\} * 100(\%)$.

${ }^{a}$ Overfeeding a mixed diet; ${ }^{b}$ overfeeding as fat; ${ }^{c}$ overfeeding as carbohydrate. 
energy being stored. Finally, Jebb et al. [20] overfed three subjects with $33 \%$ during 12 days on a mixed diet using continuous whole-body calorimetry to measure energy expenditure and substrate balance. Total energy expenditure changed by $6 \%$ and changes in fat balance accounted for $74 \%$ of the energy imbalance during overfeeding.

Eight studies measured the effect of experimental overfeeding on energy expenditure under normal daily living conditions as measured with doubly labelled water. Excluding studies in underweight subjects, adolescents and elderly, and one study with more than $100 \%$ overfeeding, four studies in healthy adults are left for review. Roberts et al. [21] overfed 7 young men for three weeks by $4.2 \mathrm{MJ} / \mathrm{d}(31 \%)$ with a typical diet. On average $85-90 \%$ of the excess energy intake was deposited. Resting expenditure increased, but at least some of this amount was obligatory expenditure associated with nutrient assimilation. No significant increase in energy expenditure for physical activity or thermoregulation resulted from overfeeding. Diaz et al. [22] overfed 9 young men by $6.2 \pm 1.9 \mathrm{MJ} / \mathrm{d}, 49 \%$ above baseline requirements, with a mixed diet for six weeks. Total energy deposition over the 42 days was $218 \mathrm{MJ}$ or $84 \%$ of excess energy intake. There was no evidence of any active energydissipating mechanisms. Levine et al. [10] fed 16 young nonobese volunteers, 4 women and 12 men, with $4.2 \mathrm{MJ} / \mathrm{d}$ $(35 \%)$ in excess of weight maintenance requirements for eight weeks. Here, energy deposition was on average only $43 \%$ of excess energy intake, ranging between individuals from $7 \%$ to $76 \%$. The remaining excess energy went to a change in resting energy, thermic effect of food and NEAT of, respectively, $8 \%$, $14 \%$ and $33 \%$ of excess energy intake. Changes in NEAT accounted for the 10 -fold differences in fat storage that occurred $(r=0.77, p<0.001)$. Joosen et al. [23] overfed 14 young women with $45 \%$ above baseline energy requirements for two weeks. Here, on average $80 \%$ of the excess, calculated as the difference between energy intake and expenditure, was deposited. There was no relation between energy deposition and changes in physical activity as recorded with a tri-axial accelerometer.

\section{Discussion}

There are not many studies where dietary fat is increased by including high-fat foods in a diet that can be consumed ad libitum. The study of Lissner et al. [13] was a short intervention over two weeks and the study of Westerterp et al. [14] was a long-term intervention over six months. Both studies showed a highly significant fat-induced increase in body weight as a consequence of overeating at the high-fat diet. The magnitude of the weight increase was less than half of what would be expected when the calculated increase in energy intake would be deposited without any costs. Firstly, the real increase in intake is likely to be smaller due to the fact that subjects might not have consumed all the food as provided or recorded. Secondly, processing and deposition of excess dietary energy increases energy expenditure (see below).

All overfeeding studies with simultaneous measurement of energy expenditure showed an overfeeding induced increase in energy expenditure (Table 1). The magnitude of the observed expenditure change was, in all but one study, within the expected range of $0 \%$ to $20 \%$ of the excess energy intake. On average $10 \%$ of the excess energy intake is required for digestion, absorption and the initial steps of metabolism. Another average $10 \%$ of the excess energy, left after deduction of this extra diet-induced energy expenditure, is required for conversion to a suitable compound for storage, i.e. carbohydrate is deposited as glycogen or fat, fat is deposited as fat, and protein is deposited as protein, glycogen or fat [24]. The study of Levine et al. [10], where the overfeeding induced increase in energy expenditure was more than $50 \%$ of excess energy intake, was exceptional. Here, the increase in energy expenditure was not only explained by dietinduced energy expenditure and storage costs but mainly by an increase in NEAT. The observed increase in NEAT does not comply with the overfeeding studies in a respiration chamber with $24 \mathrm{~h}$ monitoring of energy expenditure, where the effect of overfeeding on energy expenditure was more pronounced during the inactive part of the $24 \mathrm{~h}$ interval, i.e. the night, than during the day $[16,17]$.

A shift in the composition of the diet to a higher contribution of fats clearly facilitates overconsumption. Many studies have even concluded that the influence of fat on energy balance is independent of energy intake [25]. The studies as reviewed here showed that the fat content has an effect on body fat as a function of the effect of dietary fat on energy intake. Thus, an increase in the fat content of the diet results in an increase in energy intake and a decrease in the fat content of the diet results in a decrease of energy intake. Based on this observation, the prevalence of obesity in Western societies has been ascribed to a high fat intake [26]. National health campaigns are aimed at lowering fat intake and seem to be successful. Results from the American National Health and Nutrition Examination Survey (NHANES) show since 1980 a decline in the reported percentage of energy from fat from above $40 \mathrm{en} \%$ to below $35 \mathrm{en} \%$ [27]. However, parallel to the decrease in fat intake, the prevalence of obesity in the US has increased almost three fold [28]. The decline in fat intake in combination with the increase in obesity is known as 'the American paradox.' An explanation is bias in the assessment of dietary intake as shown by studies comparing reported intake with doubly labeled water assessed energy expenditure [29]. Underreporting of habitual intake was shown to be a common phenomenon. Additionally, underreporting of food intake does not result from a systematic underestimation of intake for all food items but seems to concern specific food items, which are generally considered 'bad for health.' Combining the results of studies showing selective underreporting of fat intake, the reported decrease in energy and fat intake in the US seems doubtful [30]. Campaigns aimed at changing food intake might not be as successful as concluded from the results of national food consumption measurements.

An increase in food intake, especially an increase in fat intake, generally results in a positive energy balance. Energy deposited as a fraction of excess energy intake, based on the studies reviewed above, ranged from $43 \%$ to $95 \%$. Excluding the study of Levine et al. [10] the range was $75 \%$ to $95 \%$. The study of Levine et al. [10] was really exceptional and has not yet been reproduced. An efficiency of energy deposition of 75 to $95 \%$ is 
in line with studies described by Blaxter [31]. He showed that, when fed above maintenance requirements, nonruminant animals and man use carbohydrate and protein for formation of new tissue with an efficiency of $62 \%$ to $77 \%$, and fat with an efficiency of $79 \%$ to $85 \%$. The difference in efficiency figures between diets is mainly determined by differences in dietinduced thermogenesis of nutrients. Reported diet induced thermogenesis values for separate nutrients are $0 \%$ to $3 \%$ for fat, $5 \%$ to $10 \%$ for carbohydrate, and $20 \%$ to $30 \%$ for protein [32]. On a mixed diet, fed above energy balance, energy balance is closely related to fat balance i.e. dietary carbohydrate and protein is oxidized and fat ingested in excess of energy requirements is stored [33]. Thus, models for the calculation of energy requirements and energy balance use an energy efficiency of $80 \%$, close to the figures for deposition of dietary fat as body fat $[34,35]$.

In conclusion, the fat content of the diet has an effect on body fat as a function of the effect of dietary fat on energy intake. There is still little evidence for adaptive thermogenesis as a response to overeating.

\section{References}

[1] Bray GA, Paeratakul S, Popkin BM. Dietary fat and obesity: a review of animal, clinical and epidemiological studies. Physiol Behav 2004;83: 549-55.

[2] Blundell JE, MacDiarmid JI. Fat as a risk factor for overconsumption: satiation, satiety, and patterns of eating. J Am Diet Assoc 1997;97(7Suppl): S63-9.

[3] Atwater WO, Bryant AP. 12th annual report (1899) of the Storrs, CT agricultural experimental station; 1990. p. 73-110.

[4] Prentice AM. Manipulation of dietary fat and energy density and subsequent effects on substrate flux and food intake. Am J Clin Nutr 1998;67(3Suppl):S535-41.

[5] Flatt JP, Ravussin E, Acheson KJ, Jequier E. Effects of dietary fat on postprandial substrate oxidation and on carbohydrate and fat balances. J Clin Invest 1985;76:1019-24.

[6] Schutz Y, Flatt JP, Jequier E. Failure of dietary fat intake to promote fat oxidation: a factor favoring the development of obesity. Am J Clin Nutr 1989;50:307-14.

[7] Thomas CD, Peters JC, Reed GW, Abumrad MM, Sun M, Hill JO Nutrient balance and energy expenditure during ad libitum feeding of highfat and high-carbohydrate diets in humans. Am J Clin Nutr 1992;55:934-42.

[8] Schrauwen P, van Marken Lichtenbelt WD, Saris WHM, Westerterp KR. Changes in fat oxidation in response to a high-fat diet. Am J Clin Nutr 1997;66:276-82.

[9] Westerterp KR, Kester ADM. Physical activity in confined conditions as an indicator of free-living physical activity. Obes Res 2003;11:8865-8.

[10] Levine JA, Eberhardt NL, Jensen MD. Role of nonexercise activity thermogenesis in resistance to fat gain in humans. Science 1999;283:212-4

[11] Astrup A. The role of dietary fat in obesity. Semin Vasc Med 2005;5:40-7.

[12] Murgatroyd PR, Coward WA. An improved method for estimating changes in whole-body fat and protein mass in man. Br J Nutr 1989;62:311-4.

[13] Lissner L, Levitsky DA, Strupp BJ, Kalkwarf HJ, Roe DA. Dietary fat and the regulation of energy intake in human subjects. Am J Clin Nutr 1987;46:886-92.
[14] Westerterp KR, Verboeket-van de Venne WPHG, Bouten CVC, De Graaf C, Van het Hof KH, Weststrate JA. Energy expenditure and physical activity in subjects consuming full- or reduced-fat diets. $\mathrm{Br} \mathrm{J}$ Nutr 1996;76:785-95.

[15] Westerterp KR, Verboeket-van de Venne WPHG, Westerterp-Plantenga MS, Velthuis-te Wierik EJM, De Graaf C, Weststrate JA. Dietary fat and body fat: an intervention study. Int J Obes 1996;20:1022-6.

[16] Dauncey M. Metabolic effects of altering the $24 \mathrm{~h}$ energy intake in man, using direct and indirect calorimetry. Br J Nutr 1980;43:257-69.

[17] Dallosso HM, James WPT. Whole-body calorimetry studies in adult men: the effect of fat over-feeding on $24 \mathrm{~h}$ energy expenditure. Br $\mathrm{J}$ Nutr 1984;52:49-64.

[18] Zed C, James WPT. Dietary thermogenesis in obesity: fat feeding at different energy intakes. Int J Obes 1986;10:375-90.

[19] Horton TJ, Drougas H, Brachey A, Reed GW, Peters JC, Hill JO. Fat and carbohydrate overfeeding in humans: different effects on energy storage. Am J Clin Nutr 1995;62:19-29.

[20] Jebb SA, Prentice AM, Goldberg GR, Murgatroyd PR, Black AE, Coward WA. Changes in macronutrient balance during over- and underfeeding assessed by 12-d continuous whole-body calorimetry. Am J Clin Nutr 1996;64:259-66.

[21] Roberts SB, Young VR, Fuss P, Fiatarone MA, Richard B, Rasmussen H, et al. Energy expenditure and subsequent nutrient intakes in overfed young men. Am J Physiol 1990;259:R461-9.

[22] Diaz EO, Prentice AM, Goldberg GR, Murgatroyd PR, Coward WA. Metabolic response to experimental overfeeding in lean and overweight healthy volunteers. Am J Clin Nutr 1992;56:641-55.

[23] Joosen AM, Bakker AH, Westerterp KR. Metabolic efficiency and energy expenditure during short-term overfeeding. Physiol Behav 2005;85: $593-7$.

[24] Westerterp KR, Donkers J, Fredrix EWHM, Boekhoudt P. Energy intake, physical activity and body weight; a simulation model. Br J Nutr 1995;73:337-47.

[25] Tucker LA, Kano MJ. Dietary fat and body fat: a multivariate study of 205 adult females. Am J Clin Nutr 1992;56:616-22.

[26] Seidell JC. Dietary fat and obesity: an epidemiological perspective. Am J Clin Nutr 1998;67(Suppl):S5546-50.

[27] Kennedy ET, Bouwman SA, Powell R. Dietary-fat intake in the US population. J Am Coll Nutr 1999;18:207-12.

[28] Spiegel AM, Alving M. Executive summary of the Strategic Plan for National Institutes of Health Obesity Research. Am J Clin Nutr 2005;82 (Suppl):S211-4.

[29] Hill RJ, Davies PSW. The validity of self-reported energy intake as determined using the doubly labeled water technique. $\mathrm{Br} \mathrm{J}$ Nutr 2001;85:415-30.

[30] Westerterp KR, Goris AHC. Validity of the assessment of dietary intake: problems of misreporting. Curr Opin Clin Nutr Metab Care 2002;5: 489-93.

[31] Blaxter K. Energy metabolism in animals and man. Cambridge: Cambridge University Press; 1989.

[32] Tappy L. Thermic effect of food and sympathetic nervous system activity in humans. Reprod Nutr Dev 1996;36:391-7.

[33] Schrauwen P, Van Marken Lichtenbelt WD, Saris WHM, Westerterp KR. The role of glycogen-lowering exercise in the change of fat oxidation in response to a high-fat diet. Am J Physiol 1997;273:E623-9.

[34] Westerterp KR, Donkers J, Fredrix EWHM, Boekhoudt P. Energy intake, physical activity and body weight; a simulation model. Br J Nutr 1995;73:337-47.

[35] Christiansen E, Garby L, Sorensen TIA. Quantitative analysis of the energy requirements for development of obesity. J Theor Biol 2005;234:99-106 